Article

\title{
Transition-metal-atom-pairs deposited on g-CN monolayer for nitrogen reduction reaction: Density functional theory calculations
}

\author{
Bin Huang a,b, Yifan Wu c, Bibo Chen a, Yong Qian a, Naigen Zhou c,\#, Neng Li b,d,e,* \\ a State Key Laboratory of Nuclear Resources and Environment, East China University of Technology, Nanchang 330031, Jiangxi, China \\ b State Key Laboratory of Silicate Materials for Architectures, Wuhan University of Technology, Wuhan 430070, Hubei, China \\ c School of Materials Science and Engineering, Nanchang University, Nanchang 330031, Jiangxi, China \\ d Shenzhen Research Institute of Wuhan University of Technology, Shenzhen 518000, Guangdong, China \\ e State Center for International Cooperation on Designer Low-Carbon \& Environmental Materials (CDLCEM), School of Materials Science and Engineering, \\ Zhengzhou University, Zhengzhou 450001, Henan, China
}

\section{A R R T I C L E I I N F}

\section{Article history:}

Received 1 September 2020

Accepted 26 November 2020

Available online 5 March 2021

\section{Keywords:}

Atom-pair catalysts

Graphitic carbon nitride monolayers

Nitrogen reduction reaction

Two-dimensional materials

Density functional theory calculations

\begin{abstract}
A B S T R A C T
The development of highly active DFT catalysts for an electrocatalytic $\mathrm{N}_{2}$ reduction reaction (NRR) under mild conditions is a difficult challenge. In this study, a series of atom-pair catalysts (APCs) for an NRR were fabricated using transition-metal (TM) atoms (TM = Sc-Zn) doped into g-CN monolayers. The electrochemical mechanism of APCs for an NRR has been reported by well-defined density functional theory calculations. The calculated limiting potentials were -0.47 and $-0.78 \mathrm{~V}$ for the $\mathrm{Fe}_{2} @ \mathrm{CN}$ and $\mathrm{Co}_{2} @ \mathrm{CN}$ catalysts, respectively. Owing to its high suppression of hydrogen evolution reactions, $\mathrm{Co}_{2} @ \mathrm{CN}$ is a superior electrocatalytic material for a $\mathrm{N}_{2}$ fixation. Stable $\mathrm{Fe}_{2} @ \mathrm{CN}$ may be a strongly attractive material for an NRR with a relatively low overpotential after an improvement in the selectivity. The two-way charge transfer affirmed the donation-acceptance procedure between $\mathrm{N}_{2}$ and $\mathrm{Fe}_{2} @ \mathrm{CN}$ or $\mathrm{Co}_{2} @ \mathrm{CN}$, which play a crucial role in the activation of inert $\mathrm{N} \equiv \mathrm{N}$ bonds. This study provides an in-depth investigation into atom-pair catalysts and will open up new avenues for highly efficient g-CN-based nanostructures for an NRR.
\end{abstract}

(C) 2021, Dalian Institute of Chemical Physics, Chinese Academy of Sciences. Published by Elsevier B.V. All rights reserved.

\section{Introduction}

Preparation methods for $\mathrm{NH}_{3}$ used as a building block in man-made medicaments, chemical fertilizers, and other applications have been an extremely active area of research in recent years $[1,2]$. The current utilization of an industrial Haber-Bosch reaction can provide a method for generating $\mathrm{NH}_{3}$ production. In this case, harsh conditions (such as high tem- perature and pressure) are needed during the operating process [3]. In addition, there are common $\mathrm{CO}_{2}$ emission problems associated with increasing environmental pressures. Serious pollution and intensive energy consumption do not conform with the sustainable development of human society. As a result, the exploration of other conversion techniques is of practical importance in alleviating energy consumption and greenhouse effects [4-8]. Among the methods for the direct transformation

\footnotetext{
* Corresponding author. E-mail: lineng@whut.edu.cn

\# Corresponding author. E-mail: ngzhou@ncu.edu.cn

This work was supported by the Overseas Expertise Introduction Project (111 project) for Discipline Innovation of China (B18038), the Basic Research Program of Shenzhen (JCYJ20190809120015163), the Fok Ying-Tong Education Foundation for Young Teachers in the Higher Education Institutions of China (161008), the Key R\&D Program of Hubei Province (2020CFA087), the Foundation of Jiangxi Educational Committee (GJJ180365), and the Foundation of Stat Key Laboratory of Nuclear Resources and Environment (NRE1411). DOI: 10.1016/S1872-2067(20)63745-7 | http://www.sciencedirect.com/journal/chinese-journal-of-catalysis | Chin. J. Catal., Vol. 42, No. 7, July 2021
} 
of $\mathrm{N}_{2}$ into $\mathrm{NH}_{3}$, electrochemical $\mathrm{N}_{2}$ reduction reactions exhibit significant potential for an efficient synthesis of $\mathrm{NH}_{3}$ in terms of energy $[9,10]$. However, the search for highly efficient and selective electrocatalysts through density functional theory (DFT) calculations remains a coveted objective owing to the inertia of diatomic $\mathrm{N}_{2}$ and side reaction competition [11,12].

The comprehensive designs of effective single-atom catalysts (SACs) for different electrocatalytic reactions have recently been studied $[13,14]$. SACs, such as Ti $[13]$, Fe $[15,16]$, Mo [17], and $\mathrm{Ru}$ [18] in various two-dimensional material supports have shown a high activity and excellent stability for $\mathrm{N}_{2}$ reduction reactions (NRRs), and their catalytic reaction mechanisms have been well documented theoretically. In addition to SACs, heterogeneous catalysts, for which double- or triple-atom catalysts have been introduced into prevailing supports (DACs or TACs), have been deemed to be a popular subject in the field of electrocatalysis [19]. In particular, atom-pair catalysts (APCs) have significant potential for many important types of electrochemical reductions of hydrogen evolution reactions (HERs) [20], $\mathrm{CO}_{2}$ reduction reactions [21], and NRRs [22-25]. For example, Jiang and coworkers demonstrated that transition-metal-atom-pairs deposited on $\mathrm{C}_{2} \mathrm{~N}$ substrates can deliver a remarkably much higher activity than those of SACs as catalysts for NRRs [22]. Compared to SACs, APCs not only provide distinctly low-coordinated metal atoms, they also ameliorate electrocatalytic reactions by adjusting any extra dispersed metal atoms. To improve the activity and selectivity of the catalysts applied, Guo et al. [24] identified 3 homonuclear and 28 heteronuclear metal-atom-pairs supported on 2D expanded phthalocyanine toward an efficient NRR, which can eliminate obstacles to metal-based activities. Therefore, flexible active sites and synergy between the two metals in APCs can provide an opportunity to increase the activity and selectivity of the catalysts.

Owing to their excellent properties, two-dimensional (2D) materials have drawn significant attention and hold great promise in the field of fundamental sciences. A new type of 2D g-CN was recently synthesized experimentally through a reaction of $\mathrm{C}_{3} \mathrm{~N}_{3} \mathrm{Cl}_{3}$ and $\mathrm{Na}$ using a simple solvothermal method [26]. These 2D materials with a high surface area and porous structure exhibit an outstanding optical activity and thermodynamic stability. Thus, 2D g-CN is used as the support to promote common reactions, including photocatalytic and electrocatalytic reactions $[27,28]$. For example, photocatalysts, fabricated using $\mathrm{N}$ atoms at the cavity in g-CN anchoring single $\mathrm{B}$ atoms, exhibit an excellent NRR performance in previous theoretical studies [27]. Theoretical studies on SACs with g-CN substrates have indicated that W@g-CN delivers a low overpotential and high selectivity with an effective suppression of HERs [28]. However, a very narrow range of parameters for the synthesis of single-atom tungsten catalysts have been considered experimentally, and tungsten is an expensive and scarce metal on earth [29]. Therefore, the search for alternative catalysts for use in 2D g-CN substrates remains a highly rewarding task.

Inspired by the successful fabrication of $\mathrm{C}_{2} \mathrm{~N}$-supported $\mathrm{Fe}$ dopant pairs, we systematically explored the fixation of $\mathrm{N}_{2}$ on various first-row transition atom-pairs supported on g-CN nanosheets [30]. Our results confirm that $\mathrm{Fe}_{2} @ \mathrm{CN}$ and $\mathrm{Co}_{2} @ \mathrm{CN}$ achieve high stability, and more importantly, exhibit an efficient $\mathrm{N}_{2}$ conversion during the NRR process. Furthermore, the NRR mechanism on $\mathrm{Co}_{2} @ \mathrm{CN}$ proceeds through a mixed pathway. These findings offer new routes for the development of highly active and low-cost atom-pair electrocatalysts.

\section{Computational details}

All spin polarization calculations were conducted using the Vienna ab initio simulation package (VASP) [31]. The projector augmented wave (PAW) method was used to treat the ion-electron interaction, and the electron interactions were depicted using the Perdew-Burke-Ernzerh (PBE) functional within the generalized gradient approximation (GGA) [32,33]. Self-consistent field convergence criteria of the residual energy and force for each atom were set to $10^{-4} \mathrm{eV}$ and $0.05 \mathrm{eV} / \AA \AA$, respectively, and the cut-off energy for the electron plane wave basis set was chosen as $460 \mathrm{eV}$ for all computations. Furthermore, a $3 \times 3 \times 1 k$-point mesh was sampled in the reciprocal space for geometry optimizations, and a $7 \times 7 \times 1 k$-point mesh was employed for the total energy and electronic structure calculations. To describe the van der Waals interactions between NRR intermediates and catalysts, the DFT-D3 empirical correction in Grimme's scheme was considered [34]. The vacuum space in the z-direction was set to $18 \AA$, which avoids the interactions between the model and mirror image. A Bader charge analysis was applied to describe the atom charges, and an analysis of the atomic configuration was conducted as implemented in the VESTA code [35,36]. The stability of the electrocatalysts was obtained based on ab initio molecular dynamics (AIMD) simulations, and the simulations of the total time and temperature were set to $4.0 \mathrm{ps}$ and $450 \mathrm{~K}$ in the NVT ensemble.

In our calculations, the method (computational hydrogen electrode) of Nørskov et al. [37] in a previous report was employed to elucidate the free energy $(\Delta G)$ diagrams. The chemical potential of an electron and proton pair $\left(\mu\left(\mathrm{H}^{+}+\mathrm{e}^{-}\right)\right)$is equal to that of half of the gaseous hydrogen $\left(\mu\left(\mathrm{H}_{2}\right)\right)$ under standard conditions $\left(p\left(\mathrm{H}_{2}\right)=1 \mathrm{~atm}, \mathrm{pH}=0\right)$. The $\Delta G$ for each elemental step can be derived as follows:

$$
\Delta G=\Delta E+\Delta E_{\mathrm{ZPE}}-T \Delta S+\Delta G_{\mathrm{U}}+\Delta G_{\mathrm{pH}}
$$

where $E$ is the electronic energy directly gained by the DFT, $\Delta E_{\mathrm{ZPE}}$ denotes the change in zero-point energy, and $T \Delta S$ is the entropy change at room temperature. The vibrational entropies of the adsorbates were computed through a frequency analysis, and entropies of gas molecules were obtained from standard data (https://janaf.nist.gov). In addition, $\Delta G_{\mathrm{U}}$ and $\Delta G_{\mathrm{pH}}$ are the changes in free energy caused by the contributions associated with the electrode potential $(U)$ and solution $\mathrm{pH}$, respectively. The potential was computed using $U=-\Delta G / \mathrm{e}$, and $U_{\text {limiting cor- }}$ responded to the most positive $\Delta G_{\mathrm{MAX}}$ among all reduction steps.

\section{Results and discussion}

\subsection{Structures and stabilities of $T M_{n} @ C N$}




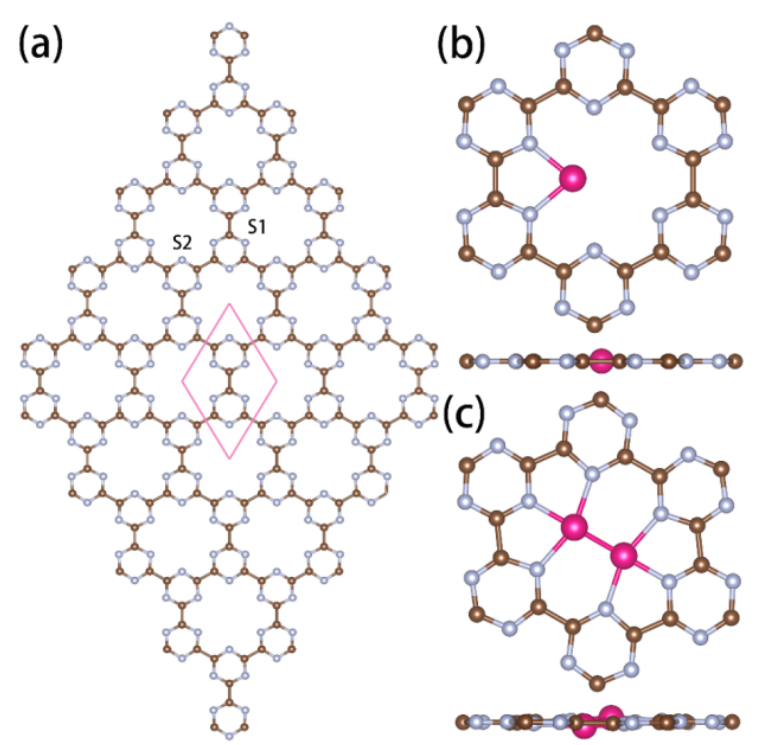

Fig. 1. (a) Structure of g-CN (the rhombus denotes the unit cell and S1 and S2 represent adsorption sites of single metal atom); structures of single metal atom (b) and metal dimer dopant (c) on g-CN. The pink, brown, and light-blue balls denote metal, carbon, and nitrogen atoms, respectively.

The optimized geometry of g-CN is depicted in Fig. 1(a), and the rhombus denotes the unit cell. In the monolayer $\mathrm{CN}$, the triazine rings are bridged by $\mathrm{C}-\mathrm{C}$ bonds, which form a six-fold nitrogen cavity. The corresponding lattice parameter is $7.12 \AA$, and the calculated band gap is $3.22 \mathrm{eV}$ (Fig. S1), which matches well with the experimental data and DFT results $[27,38]$. In addition, each of the two nitrogen atoms face each other at a distance of $5.46 \AA$, which is slightly smaller than that of the $\mathrm{C}_{2} \mathrm{~N}$ nanosheet ( $5.52 \AA)$. Ten types of $3 d$ metal atoms (TM = Sc-Zn) are accommodated on the six-member ring of the g-CN monolayer as the catalyst substrate because of the small number of holes in the CN nanosheet. The sites S1 and S2 in Fig. 1(a) represent the adsorption sites of a single metal atom, and schematic diagrams of a single TM atom (denoted as TM@CN) and double TM atoms (denoted as $\mathrm{TM}_{2} @ \mathrm{CN}$ ) dopant on g-CN are shown in Figs. 1(b,c), respectively (more details of the structures are shown in Figs. S2 and S3). After a single TM decoration, TM@CN maintains its planar structure in all catalysts, which is consistent with a previous study [26]. However, the TM dopant pairs in some $\mathrm{TM}_{2} @ \mathrm{CN}$ catalysts moderately protrude out of the g-CN monolayer, resulting in buckled structures except for $\mathrm{Co}_{2} @ \mathrm{CN}$ and $\mathrm{Ni}_{2} @ \mathrm{CN}$. This is mainly because the late periodic table TM element of the radii decreases.

To determine whether APCs for the selected TM atoms can be formed, we first examined the binding energy of a single TM atom and double TM atoms on the g-CN substrate. The average binding energy of the selected atoms on the substrate is more negative than that of a single atom, which indicates that a $\mathrm{TM}_{2} @ \mathrm{CN}$ form is preferable. Here, $E_{\mathrm{b}}$ is evaluated according to the following formula:

$$
E_{\mathrm{b}}=\left(E_{\mathrm{TMn} @ \mathrm{~g}-\mathrm{CN}}-E_{\mathrm{g}-\mathrm{CN}}-n E_{\mathrm{TM}}\right) / n
$$

where $E_{\mathrm{TMn} @ \text { g-CN, }} E_{\mathrm{g}-\mathrm{CN}}$, and $E_{\mathrm{TM}}$ are the energies of the catalysts, g-CN monolayer, and single TM atom, respectively. Fig. 2 shows the calculated binding energies of single and double metal at-

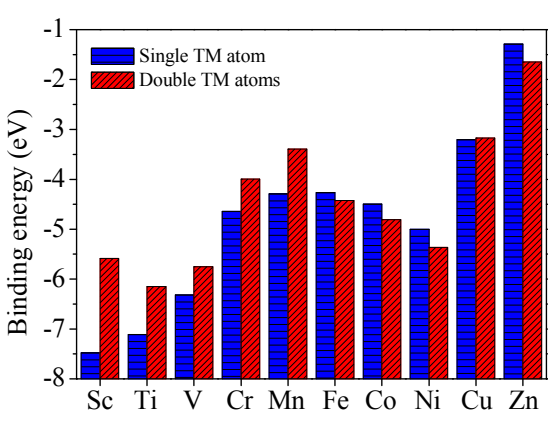

Fig. 2. Calculated binding energies versus the number of TM atoms.

oms on g-CN nanosheets. For a single atom on the g-CN substrate, the calculated $E_{\mathrm{b}}$ in $\mathrm{TM}_{\mathrm{n}} @ \mathrm{CN}$ (Sc, Ti, V, Cr, Mn, and $\mathrm{Cu}$ ) indicates a low probability for the dimer formation. However, the computed $E_{\mathrm{b}}$ values for $\mathrm{TM}_{2} @ \mathrm{CN}(-4.43,-4.81,-5.37$, and $-1.64 \mathrm{eV}$ for $\mathrm{Fe}, \mathrm{Co}, \mathrm{Ni}$, and $\mathrm{Zn}$, respectively) were more negative than those of TM@CN $(-4.26,-4.50,-5.00$, and $-1.29 \mathrm{eV}$ for $\mathrm{Fe}, \mathrm{Co}, \mathrm{Ni}$, and $\mathrm{Zn}$, respectively). In addition, the adsorption strength of the second TM atom for Fe, Co, Ni, and Zn@CN is significantly enhanced (Table S2), which implies that the second TM atom added to these TM@CN structures can effectively form $\mathrm{TM}_{2} @ C N$ [39]. Subsequently, we continued to adhere a single $\mathrm{TM}$ ( $\mathrm{Fe}, \mathrm{Co}, \mathrm{Ni}$, or $\mathrm{Zn}$ ) atom to the corresponding TM2 dimer, which determines whether the metal trimer forms easily on g-CN. From our optimized structures, it was found that the formation of $\mathrm{Zn}$ trimer on $\mathrm{g}$ - $\mathrm{CN}$ is very difficult due to single $\mathrm{Zn}$ atom detachment from the substrate. The association energy (Eas) [40] for $\mathrm{Fe}$, Co, or $\mathrm{Ni}$ was calculated using the following formula:

$$
E_{\mathrm{as}}=E_{\mathrm{TM} 3 @ \mathrm{~g}-\mathrm{CN}}+E_{\mathrm{g}_{-} \mathrm{CN}}-E_{\mathrm{TM} 1 @ \mathrm{~g}-\mathrm{CN}}-E_{\mathrm{TM} 2 @ \mathrm{~g}-\mathrm{CN}}
$$

where $E_{\mathrm{TM} 3 @ \mathrm{~g}-\mathrm{CN}}, E_{\mathrm{TM} 2 @ \mathrm{~g}-\mathrm{CN}}$, and $E_{\mathrm{TM} 1 @ \mathrm{~g}-\mathrm{CN}}$ are the energies of the containing metal trimers, metal dimers, and single metal atom catalysts, respectively. The positive $E_{\text {as }}$ calculated for the three catalysts indicates the difficulty in forming metal trimers on a g-CN substrate (Table S2). To examine the electronic structure of the four catalysts, band structures were obtained (Fig. S4). For all catalysts, the calculated band gaps rapidly decrease compared to the band gap of $\mathrm{g}$ - $\mathrm{CN}$ because the d-bands of the metal atom pairs are mixed into the band gap of the substrate. The improved conductivity of the APCs is beneficial to the electrocatalytic reaction. Thus, we identified several candidate metal atom-pair catalysts $\left(\mathrm{Fe}_{2}, \mathrm{Co}_{2}, \mathrm{Ni}_{2}\right.$, and $\left.\mathrm{Zn}_{2} @ \mathrm{CN}\right)$ for further reduction reactions.

\subsection{Activating $\mathrm{N}_{2}$ on $T M_{2} @ C N$}

The effective capture of $\mathrm{N}_{2}$ on $\mathrm{TM}_{2} @ \mathrm{CN}$ is of paramount importance for initializing a further reaction. Thus, we first evaluated the adsorption of $\mathrm{N}_{2}$ on different APCs. The optimized configurations with two adsorption modes and the corresponding $\Delta G^{*} \mathrm{~N} 2$ on the APC surface are shown in Fig. 3. The calculated negative $\Delta G^{*}$ N2 values indicate that $\mathrm{N}_{2}$ adsorbed easily on $\mathrm{TM}_{2} @ \mathrm{CN}$ under ambient conditions. It was found that $\mathrm{N}_{2}$ with end-on or side-on modes on $\mathrm{Ni}_{2} @ \mathrm{CN}$ and $\mathrm{Zn}_{2} @ \mathrm{CN}$ are unfavorable owing to the positive adsorption free energy (Figs. 


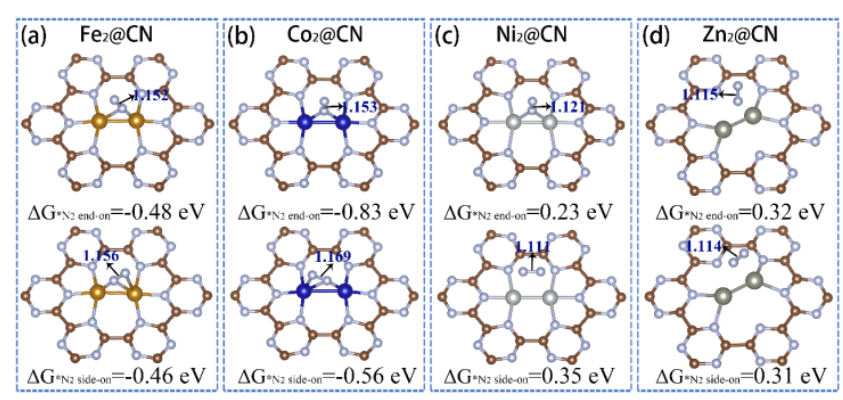

Fig. 3. The calculated free-energy change in $\mathrm{N}_{2}$ adsorption on $\mathrm{TM}_{2} @ \mathrm{CN}$ (the unit of the bond length is $\AA$ ).

3(c,d)). By contrast, the calculated $\Delta G^{*} \mathrm{~N} 2$ is -0.48 and $-0.46 \mathrm{eV}$ on $\mathrm{Fe}_{2} @ \mathrm{CN}$, and -0.83 and $-0.56 \mathrm{eV}$ on $\mathrm{Co}_{2} @ \mathrm{CN}$ with end and side modes, respectively, which indicates that $\mathrm{N}_{2}$ can be trapped more efficiently on the two catalyst surfaces. Note that the structure of $\mathrm{N}_{2}$ adsorption with the side mode on $\mathrm{Fe}_{2} @ \mathrm{CN}$ after full optimization is similar to that of the end mode. This feature is consistent with the $\mathrm{N}_{2}$ adsorption on $\mathrm{Fe}_{2} @ \mathrm{C}_{2} \mathrm{~N}$ in a previous study [39]. In these steps, the bond length $\mathrm{N}-\mathrm{N}$ for the adsorbed $\mathrm{N}_{2}$ species was within the range of 1.111-1.169 ̊. The spin moment of the catalysts is a crucial factor for $\mathrm{N}_{2}$-activation. In the case of $\mathrm{Fe}_{2} @ \mathrm{CN}$, the calculated spin moment is $3.88 \mu \mathrm{B}$, which is primarily situated on the $\mathrm{Fe}$ atom pairs. After $\mathrm{N}_{2}$ adsorption, the corresponding spin moment is reduced to $2.00 \mu \mathrm{B}$, and this change is reflect in the shift from $\mathrm{Fe}$ atom pairs to the inert $\mathrm{N}_{2}$, which is advantageous to the $\mathrm{N}_{2}$-activation (Fig. S5).

The enhanced interactions between $\mathrm{N}_{2}$ and $\mathrm{Fe}_{2} @ \mathrm{CN}$ or Co2@CN were also attributed to the occupied and empty $d$ orbitals of the TM2 active centers [23]. Fig. S6 shows the partial density of states for $\mathrm{N}_{2}$ adsorption with the end mode on $\mathrm{Fe}_{2} @ \mathrm{CN}$ and $\mathrm{Co}_{2} @ \mathrm{CN}$, respectively. We found that the empty $d$ orbitals of the TM atom pairs can obtain electrons from the $\mathrm{N}_{2}$, and the TM dimers can simultaneously give electrons into the $\pi^{*}$ orbital of $\mathrm{N}_{2}$. Therefore, the $\mathrm{N}-\mathrm{N}$ bond is weakened, which leads to a strong adsorption free energy of $\mathrm{N}_{2}$ on the catalyst surfaces. Based on the above calculated results, it seems that $\mathrm{N}_{2}$ can be effectively activated on the Fe2@CN and $\mathrm{Co}_{2} @ \mathrm{CN}$ catalysts, which is beneficial for a further NRR.

\subsection{Electrochemical mechanism reducing $\mathrm{N}_{2}$ to $\mathrm{NH}_{3}$}

To investigate the NRR mechanism on $\mathrm{TM}_{2} @ \mathrm{CN}$ used in our study, distinct reaction paths are displayed in Scheme 1. Three possible reaction mechanisms (distal, alternating, and enzymatic) through different intermediates for an NRR have been proposed, the electroreduction process of which involves consecutive proton/electron $\left(\mathrm{H}^{+}+\mathrm{e}^{-}\right)$pair gains. It is generally believed that the reaction $* \mathrm{~N}_{2}+\left(\mathrm{H}^{+}+\mathrm{e}^{-}\right) \rightarrow{ }^{*} \mathrm{~N}_{2} \mathrm{H}$ or $* \mathrm{NH}_{2}+\left(\mathrm{H}^{+}\right.$ $\left.+\mathrm{e}^{-}\right) \rightarrow{ }^{*} \mathrm{NH}_{3}$ is the PDS of an NRR on SACs, which discloses a basic reduction step with the highest $\Delta G$ value. In general, it is difficult to initiate an NRR for the hydrogenation steps with a large $\Delta G$ value. If $\Delta G_{\mathrm{PDS}}<0.8 \mathrm{eV}$ for one of the hydrogenation steps in our calculations, we believe that APCs have a better catalytic activity for an NRR [39]. Thus, the reaction free ener-

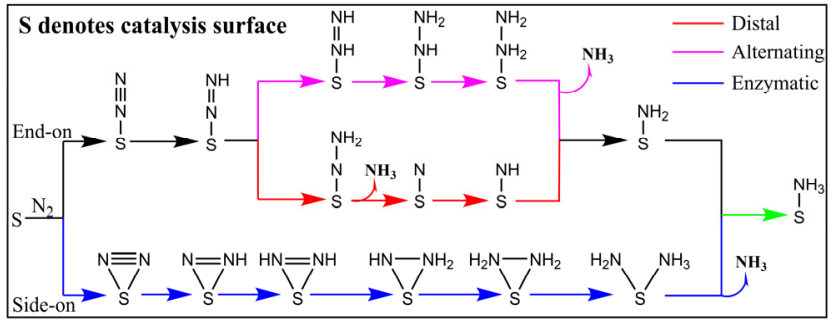

Scheme 1. Schematic diagram of possible reaction pathways for NRR on $\mathrm{TM}_{2} @ \mathrm{CN}$.

gies ( ${ }^{*} \mathrm{~N}_{2} \mathrm{H}$ and ${ }^{*} \mathrm{NH}_{3}$ formation) on $\mathrm{TM}_{2} @ \mathrm{CN}$ were determined. Table S3 summarizes the corresponding free energy changes for $\mathrm{Fe}_{2} @ \mathrm{CN}$ and $\mathrm{Co}_{2} @ \mathrm{CN}$. The calculated $\Delta G$ of PDS is 0.47 and 0.78 eV by the distal pathway on Fe2@CN and Co2@CN, respectively. When the NRR follows the enzymatic pathways on $\mathrm{Co}_{2} @ \mathrm{CN}, \mathrm{PDS}$ is the formation of the *NNH intermediate with a high $\Delta G$ value of $1.07 \mathrm{eV}$, indicating that the enzymatic mechanism was unfavorable. As a result, Fe and Co dimer anchored $\mathrm{CN}$ nanosheets achieve a better catalytic performance with the end-on adsorption mode of dinitrogen on a two catalyst surface.

To further confirm the potential electrocatalytic performance of the TM2@CN monolayer, the entire reaction pathways were investigated using distal and alternating mechanisms based on the energetically favorable adsorption configurations. Only the TM dimer center was considered for an NRR because the $\mathrm{N}$ atom of $\mathrm{g}-\mathrm{CN}$ is reduced with a much higher positive free energy change [28]. Fig. 4 shows the structural configurations of both mechanisms on the surface of the $\mathrm{TM}_{2} @ \mathrm{CN}$, and the reaction-free energy of an NRR is shown in Fig. 5.

For the distal mechanism of the promising Fe $@ \mathrm{CN}$, the first $\left(\mathrm{H}^{+}+\mathrm{e}^{-}\right)$pair is transferred to the remote $\mathrm{N}$ site of $\mathrm{N}_{2}$, reaching the ${ }^{*} \mathrm{~N}_{2} \mathrm{H}$ intermediate species adsorbed on the bridge site of the Fe dimer (Fig. 4(a)). In this structure, the adsorbate of the $\mathrm{N}-\mathrm{N}$ bond length is elongated to $1.234 \AA$, and this reaction step is thermodynamically endothermic, which is computed as 0.47 $\mathrm{eV}$. From the ${ }^{*} \mathrm{~N}_{2} \mathrm{H}$ intermediate, the $\left(\mathrm{H}^{+}+\mathrm{e}^{-}\right)$pair consecutively attacks the remote $\mathrm{N}$ atom of the ${ }^{*} \mathrm{~N}_{2} \mathrm{H}$ adsorbate, producing a ${ }^{*} \mathrm{~N}_{2} \mathrm{H}_{2}$ intermediate with an increase in the value of $\Delta G(0.21$ $\mathrm{eV}$ ). Then, one $\mathrm{NH}_{3}$ molecule can be released during the next reduction step. In this step, the optimized Fe-N bond length is $1.667 \AA$, and $\Delta G$ is reduced by $0.53 \mathrm{eV}$. To obtain the other $\mathrm{NH}_{3}$, the remaining $* \mathrm{~N}$ reduction process was considered owing to a gain in three successive $\left(\mathrm{H}^{+}+\mathrm{e}^{-}\right)$pairs. The adsorption-free energy changes of ${ }^{*} \mathrm{NH},{ }^{*} \mathrm{NH}_{2}$, and ${ }^{*} \mathrm{NH}_{3}$ are calculated as -0.38 , -0.76 , and $+0.46 \mathrm{eV}$, respectively. We noted that the $\mathrm{NH}_{3}$ desorption from the $\mathrm{Fe}_{2} @ \mathrm{CN}$ monolayer required supply-free energy $(0.36 \mathrm{eV})$. However, during the experiments, the second $\mathrm{NH}_{3}$ molecule on the electrocatalyst may also be easily desorbed by $\mathrm{NH}_{4}{ }^{+}$ions in an acidic solution. Thus, the PDS is the $\left(\mathrm{H}^{+}+\mathrm{e}^{-}\right.$) pair transfer step of ${ }^{*} \mathrm{~N}_{2}$ (i.e., ${ }^{*} \mathrm{~N}_{2} \rightarrow{ }^{*} \mathrm{~N}_{2} \mathrm{H}$ ) among all electro-reaction steps involved.

For the alternating pathway, the reduction alternately occurs at the two $\mathrm{N}$ atoms, and the first $\mathrm{NH}_{3}$ was released as a fifth-reduced species. The PDS of $\Delta G$ on the $\mathrm{Fe}_{2} @ \mathrm{CN}$ monolayer 


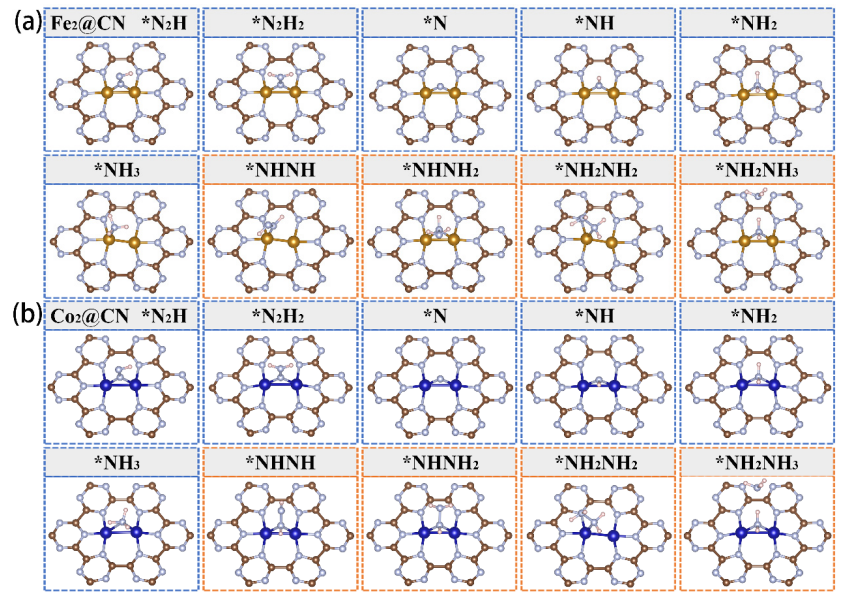

Fig. 4. Optimized geometric structures of various intermediates along distal (blue dotted frame) and alternating (orange dotted frame) mechanisms on (a) $\mathrm{Fe}_{2} @ \mathrm{CN}$ and (b) $\mathrm{Co}_{2} @ \mathrm{CN}$ electrocatalysis surfaces.

is the formation of the * NHNH intermediate with an energy barrier of $1.07 \mathrm{eV}$ (Fig. 5(b)). In addition, we found that the ${ }^{*} \mathrm{NH}_{2} \mathrm{NH}_{2}$ intermediate exhibits a weak interaction with the substrate, which is easily produced by the product $\mathrm{NH}_{2} \mathrm{NH}_{2}$. Clearly, the NRR was unfavorable owing to the alternating mechanism of the $\mathrm{Fe}_{2} @ \mathrm{CN}$ catalyst.

For the $\mathrm{Co}_{2} @ \mathrm{CN}$ catalyst, the reduction processes of the change in free energy are almost the same as those of the $\mathrm{Fe}_{2} @ \mathrm{CN}$ catalyst using a distal or alternating mechanism. However, the calculated PDS for $\mathrm{Co}_{2} @ \mathrm{CN}$ with 0.78 or $0.87 \mathrm{eV}$ is the formation of ${ }^{*} \mathrm{NH}_{3}$ or ${ }^{*} \mathrm{NH}_{2} \mathrm{NH}_{2}$ species in a distal or alternating mechanism, respectively. The calculated results indicate that the $U_{\text {limiting }}$ of $\mathrm{Co}_{2} @ \mathrm{CN}$ is more negative than that of $\mathrm{Fe}_{2} @ \mathrm{CN}$, which is mainly attributed to the self-adaption and electronic transformation on g-CN nanosheets. It should be noted that the actual NRR mechanism is extremely complex and all three reaction mechanisms are involved in the minimum energy pathway. DFT calculations have recently shown
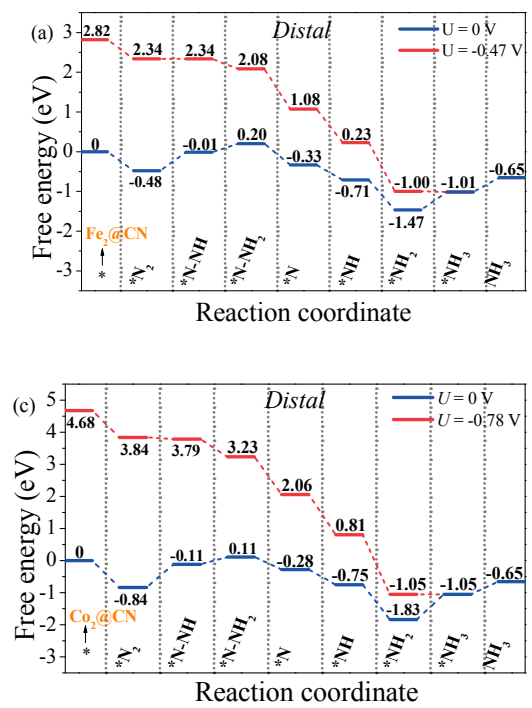

that a mixed mechanism for an NRR is feasible in a catalyst, and thus, a mixed pathway has been considered for $\mathrm{Fe}_{2} @ \mathrm{CN}$ and Co2@CN catalysts [41]. According to our computations, a mixed mechanism is energetically less favorable than a distal mechanism for $\mathrm{Fe}_{2} @ \mathrm{CN}$ (Fig. S7). For a $\mathrm{Co}_{2} @ \mathrm{CN}$ catalyst, the key intermediate ${ }^{*} \mathrm{NHNH}_{2}$ was hydrogenated, leading to two adsorbates $\left(* \mathrm{NH}+\mathrm{NH}_{3}\right.$ or $\left.{ }^{*} \mathrm{NH}_{2}-\mathrm{NH}_{2}\right)$. The free energy of the former is downhill $0.43 \mathrm{eV}$, whereas the latter has a positive free energy change in the alternating mechanism and produces the byproduct $\mathrm{NH}_{2} \mathrm{NH}_{2}$. In addition, the PDS of the mixed mechanism is the same as the distal mechanism, which is the formation of ${ }^{*} \mathrm{NH}_{3}$. In terms of the above free energy results, we observed the effective minimum energy path and a more positive limiting potential on TM2@CN.

\subsection{Activity and selectivity of NRR on the TM2@g-CN}

A Bader charge analysis was further conducted to inspect the excellent catalytic activity of $\mathrm{Fe}_{2} @ \mathrm{CN}$ and $\mathrm{Co}_{2} @ \mathrm{CN}$ along the distal reaction pathway. According to previous studies, each intermediate was divided into three moieties, including moiety $1\left(\mathrm{~N}_{x} \mathrm{H}_{y}\right)$, moiety 2 (metal dimer), and moiety 3 (g-CN substrate). As shown in Fig. 6, the $\mathrm{N}_{2}$ molecule in $\mathrm{Fe}_{2} @ \mathrm{CN}$ accumulates 0.05 more electrons than that in $\mathrm{Co}_{2} @ \mathrm{CN}$, and the first protonation of $\Delta G$ required is lowered by $0.31 \mathrm{eV}$. This is mainly because ${ }^{*} \mathrm{~N}_{2}$ will easily form ${ }^{*} \mathrm{NNH}$ when more negative electrons accumulate in ${ }^{*} \mathrm{~N}_{2}$. In addition, Fe or Co dimers are accommodated as cations in the substrate with the injection of charges from $\mathrm{Fe}_{2}$ or $\mathrm{Co}_{2}$ to the $\mathrm{N} p$ orbitals of g-CN. In the subsequent NRR process, a charge fluctuation was clearly observed in the three moieties. Hence, the metal dimers serve as transmitters for an electron transfer between intermediates and the g-CN monolayer, and the g-CN substrate acts as an electron reservoir for the regulation of the charge in the NRR cycle.

Based on the above charge calculations, we found that the Fe or Co dimer on the g-CN monolayer possesses an electropositive charge, and that these TM dimer centers may also bind to
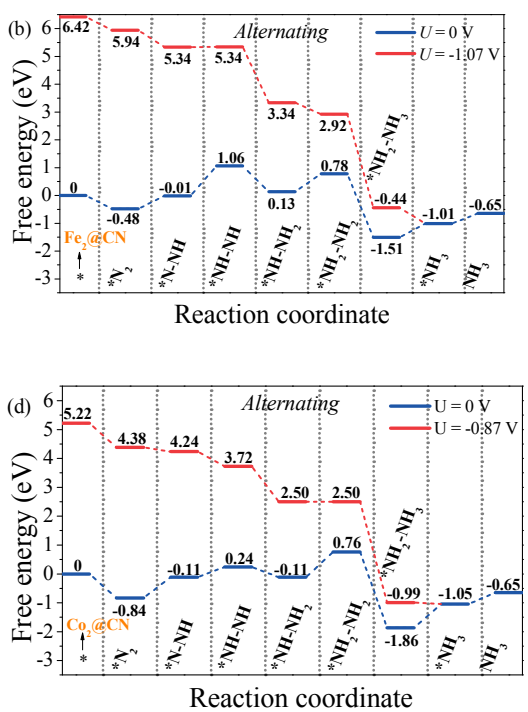

Fig. 5. Free energy diagrams at zero and applied potential (limiting potential) through distal $(\mathrm{a}, \mathrm{c})$ and alternating $(\mathrm{b}, \mathrm{d}) \mathrm{mechanisms} \mathrm{on} \mathrm{Fe}_{2} @ \mathrm{CN}(\mathrm{a}, \mathrm{b})$ and $\mathrm{Co}_{2} @ \mathrm{CN}(\mathrm{c}, \mathrm{d})$, respectively. 

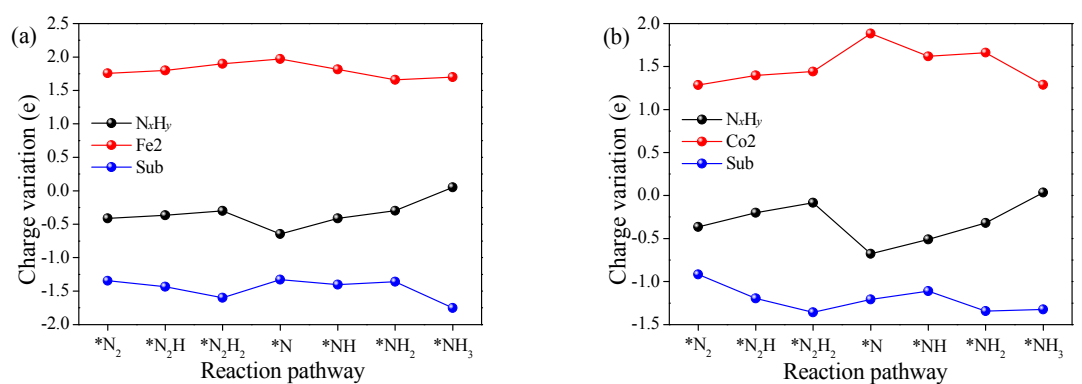

Fig. 6. Charge state of each moiety in (a) $\mathrm{Fe}_{2} @ \mathrm{CN}$ and (b) $\mathrm{Co}_{2} @ \mathrm{CN}$ based on distal mechanism.

other negative entities, such as lone pairs (on $\mathrm{CO}_{2}$ or $\mathrm{H}_{2} \mathrm{O}$ molecules) [42]. For comparison, $\mathrm{CO}_{2}$ and $\mathrm{H}_{2} \mathrm{O}$ adsorption-free energies were calculated to determine whether $\mathrm{CO}_{2}$ and $\mathrm{H}_{2} \mathrm{O}$ can hamper $\mathrm{N}_{2}$ adsorption on the catalyst surface. As Fig. S8 shows, the $\mathrm{CO}_{2}$ molecule exhibits physisorption on two selected catalyst surfaces, which indicates that the capture of $\mathrm{CO}_{2}$ is unfavorable. In addition, $\mathrm{H}_{2} \mathrm{O}$ is also less negative than $\mathrm{N}_{2}$ chemisorption. In other words, $\mathrm{Fe}_{2} @ \mathrm{CN}$ and $\mathrm{Co}_{2} @ \mathrm{CN}$ catalysts interact preferentially with $\mathrm{N}_{2}$ rather than $\mathrm{H}_{2} \mathrm{O}$, which is theoretically promising for $\mathrm{N}_{2}$ capture in a humid or aqueous environment. Previous studies have shown that the HER significantly affects the Faradaic efficiency of an NRR [18,24]. Therefore, we further calculated the free energy changes $\left(\Delta G^{*} \mathrm{H}\right)$ on the catalyst surface. As shown in Fig. S9, the calculated free energies of HER are -0.476 and -0.698 eV for $\mathrm{Fe}_{2} @ \mathrm{CN}$ and $\mathrm{Co}_{2} @ \mathrm{CN}$, respectively, indicating that $\mathrm{H}$ strongly interacts with the catalysts. In combination with $\Delta G^{*} \mathrm{~N} 2$, we found that $\mathrm{N}_{2}$ activation would be less hampered compared to $\mathrm{H}$ adsorption on $\mathrm{Co}_{2} @ \mathrm{CN}$, indicating a high selectivity. For the Fe $2 @ \mathrm{CN}$ catalyst
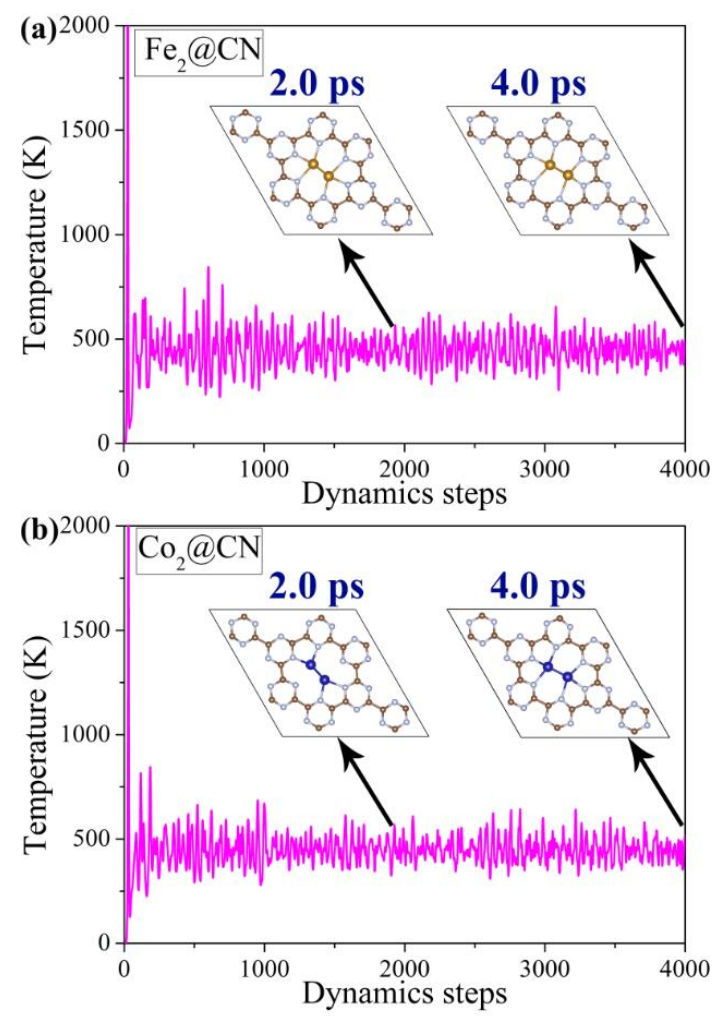

Fig. 7. Two snapshots from AIMD simulations on $\mathrm{Fe}_{2} @ \mathrm{CN}$ (a) and Co2@CN (b) at 450 K. with low $U_{\text {limiting, }} \Delta G{ }^{*}{ }_{\mathrm{N} 2}(-0.48 \mathrm{eV})$ is slightly negative than $\Delta G^{*} \mathrm{H}$ $(-0.476 \mathrm{eV})$, leading to competition between an HER and an NRR. Furthermore, the selectivity is estimated by comparing $U_{\text {limiting }}$ of an HER and an NRR during the NRR process. The calculated results ( $U_{\mathrm{L}}(\mathrm{NRR})-U_{\mathrm{L}}(\mathrm{HER})$ ) were 0.01 and $-0.09 \mathrm{~V}$ for $\mathrm{Fe}_{2} @ \mathrm{CN}$ and $\mathrm{Co}_{2} @ \mathrm{CN}$, respectively, which are positive compared to the benchmark $(-0.5 \mathrm{~V})$ on the metal-based catalyst, indicating that both catalysts possess high selectivity [43].

The potential $(U)$ can characterize the electrochemical reactivity, in which more negative $U$ values exhibit a slow rate of $\mathrm{N}_{2}$ reduction. In recent observations, $\mathrm{W}$ supported on g-CN nanosheets can deliver a potential $(-0.34 \mathrm{~V})$ for an NRR through a first principle study. Although W@CN shows a high efficiency regarding a $\mathrm{N}_{2}$ fixation, single-atom tungsten catalysts for a synthesis are relatively complicated during the experiments, and tungsten is an expensive and scarce metal. Previous studies have also indicated that single $\mathrm{W}$ atoms aggregate easily on single-defect graphene [44]. In addition, the identified $\mathrm{Fe}_{2} @ \mathrm{CN}$ and $\mathrm{Co}_{2} @ \mathrm{CN}$ catalysts exhibit a lower potential than those of single $\mathrm{Fe}$ or $\mathrm{Co}$ atoms anchoring to a $\mathrm{C}_{2} \mathrm{~N}$ or $\mathrm{CN}$ monolayer, which shows that APCs can deliver a high NRR activity through a synergic effect $[28,39]$. In addition to SACs, metal-based materials, particularly pure metal surfaces, have been frequently used for NRR tests. As previously reported, the well-established $\mathrm{Ru}$ (0001) stepped surface can deliver a moderate potential (approximately $1.0 \mathrm{~V}$ ) for a $\mathrm{N}_{2}$ fixation. However, ${ }^{*} \mathrm{H}$ is easily adsorbed on most pure metal surfaces, which leads to a poor activity of the catalysts during the NRR process [45]. Thus, the deposited Fe and Co atom pairs on the g-CN nanosheet are expected to be prospective APCs for a $\mathrm{N}_{2}$ fixation.

Finally, the corresponding thermal stability is considered through a first-principles molecular dynamics simulation. Fig. 7 shows two snapshots of $\mathrm{Fe}_{2} @ \mathrm{CN}$ and $\mathrm{Co}_{2} @ \mathrm{CN}$ catalysts at a time of 2.0 and $4.0 \mathrm{ps}$. The simulation results indicate that the Fe dimer is well fixed in the holes of the $\mathrm{CN}$, and Fe or Co clustering is absent, which exhibits the high structural stability of Fe2@CN and Co2@CN.

\section{Conclusions}

To summarize, transition-metal-atom pairs $(\mathrm{TM}=\mathrm{Sc}-\mathrm{Zn})$ supported on g-CN ( $\left.\mathrm{TM}_{2} @ \mathrm{CN}\right)$ were evaluated in terms of a potential $\mathrm{N}_{2}$ reduction of electrocatalysts through density functional theory calculations. Based on the binding strength of a 
single atom and an atom pair on a g-CN nanosheet, we screened out four atom-pair catalysts as electrode materials for an NRR. The mutual charge transfer between $\mathrm{N}_{2}$ and $\mathrm{Fe}_{2} @ \mathrm{CN}$ or $\mathrm{Co}_{2} @ \mathrm{CN}$ has been affirmed through the donation-acceptance procedure, which plays a crucial role in the activation of inert $\mathrm{N}-\mathrm{N}$ bonds. On $\mathrm{Fe}_{2} @ \mathrm{CN}$, the calculated $U_{\text {limiting }}$ is $-0.47 \mathrm{~V}$ for an NRR through the distal mechanism, which is accompanied by an HER competition. For $\mathrm{Co}_{2} @ \mathrm{CN}$, the calculated $U_{\text {limiting }}$ is $-0.78 \mathrm{~V}$ through a distal or mixed mechanism with a high selectivity of the NRR. Thus, our results indicate that stable $\mathrm{Co}_{2} @ \mathrm{CN}$ may be a highly attractive material for an NRR with a relatively low overpotential and high selectivity. We believe that this study will further enhance the attention of the NRR research community toward atom-pair catalysts.

\section{References}

[1] B. M. Hoffman, D. Lukoyanov, Z. Y. Yang, D. R. Dean, L. C. Seefeldt, Chem. Rev., 2014, 114, 4041-4062.

[2] B. H. R. Suryanto, H. L. Du, D. B. Wang, J. Chen, A. N. Simonov, D. R. MacFarlane, Nat. Catal., 2019, 2, 290-296.

[3] S. L. Foster, S. I. P. Bakovic, R. D. Duda, S. Maheshwari, R. D. Milton, S. D. Minteer, M. J. Janik, J. N. Renner, L. F. Greenlee, Nat. Catal., 2018, 1, 490-500.

[4] T. Zhu, J. Ding, Q. Shao, Y. Qian, X. Huang, ChemCatChem, 2019, 11, 689-692.

[5] M. Zhu, Q. Shao, Y. Qian, X. Huang, Nano Energy, 2019, 56, 330-337.

[6] G. L. Xu, H. B. Zhang, J. Wei, H. X. Zhang, X. Wu, Y. Li, C. S. Li, J. Zhang, J. H. Ye, ACS Nano, 2018, 12, 5333-5340.

[7] S. Kattel, P. J. Ramírez, J. G. Chen, J. A. Rodriguez, P. Liu, Science, 2017, 355, 1296-1299.

[8] W. H. Ren, X. Tan, W. F. Yang, C. Jia, S. M. Xu, K. X. Wang, S. C. Smith, C. Zhao, Angew. Chem. Int. Ed., 2019, 58, 6972-6976

[9] Y. Chen, R. J. Guo, X. Y. Peng, X. Q. Wang, X. J. Liu, J. Q. Ren, J. He, L. C. Zhuo, J. Q. Sun, Y. F. Liu, Y. Wu, J. Luo, ACS Nano, 2020, 14, 6938-6946.

[10] L. Q. Li, C. Tang, B. Q. Xia, H. Y. Jin, Y. Zheng, S. Z. Qiao, ACS Catal., 2019, 9, 2902-2908.

[11] L. M. Azofra, N. Li, D. R. MacFarlane, C. H. Sun, Energy Environ. Sci.,
2016, 9, 2545-2549.

[12] C. Choi, S. Back, N. Y. Kim, J. Lim, Y. H. Kim, Y. S. Jung, ACS Catal,, 2018, 8, 7517-7525.

[13] X. Z. Chen, X. J. Zhao, Z. Z. Kong, W. J. Ong, N. Li, J. Mater. Chem. A, 2018, 6, 21941-21948.

[14] B. Li, Y. Wu, N. Li, X. Z. Chen, X. B. Zeng, Arramel, X. J. Zhao, J. Z. Jiang, ACS Appl Mater Interfaces, 2020,12, 9261-9267.

[15] L. M. Azofra, C. H. Sun, L. Cavallo, D. R. MacFarlane, Chem. Eur. J., 2017, 23, 8275-8279.

[16] Y. J. Gao, H. Zhuo, Y. Y. Cao, X. Sun, G. Zhuang, S. W. Deng, X. Zhong, Z. Z. Wei, J. G. Wang. Chin. J. Catal, 2019, 40, 152-159.

[17] B. Huang, N. Li, W. Ong, N. Zhou, J. Mater. Chem. A, 2019, 7, 27620-27631.

[18] X. Liu, Y. Jiao, Y. Zheng, M. Jaroniec, S. Z. Qiao, J. Am. Chem. Soc., 2019, 141, 9664-9672.

[19] Z. W. Chen, L. X. Chen, C. C. Yang, Q. Jiang, J. Mater. Chem. A, 2019, 7, 3492-3515.

[20] X. Liu, Y. Jiao, Y. Zheng, K. Davey, S. Z. Qiao, J. Mater. Chem. A, 2019, 7, 3648-3654.

[21] Y. Li, H. Su, S. H. Chan, Q. Sun, ACS Catal, 2015, 5, 6658-6664.

[22] Z. W. Chen, J. Yan, Q. Jiang, Small Methods, 2018, 1800291.

[23] F. Li, Q. Tang, Nanoscale, 2019, 11, 18769-18778.

[24] X. Y. Guo, J. X. Gu, S. R. Lin, S. L. Zhang, Z. F. Chen, S. P. Huang, J. Am. Chem. Soc., 2020, 142, 5709-5721.

[25] Y. M. Qian, Y. Y. Liu, Y. Zhao, X. H. Zhang, G. H. Yu, EcoMat, 2020, 2, e12014.

[26] J. Li, C. Cao, J. Hao, H. Qiu, Y. Xu, H. Zhu, Diam. Relat. Mater., 2006, 15, 1593-1600.

[27] X. S. Lv, W. Wei, F. P. Li, B. B. Huang, Y. Dai, Nano Lett., 2019, 19, 9, 6391-6399.

[28] S. H. Wang, W. Wei, X. S. Lv, B. B. Huang, Y. Dai, J. Mater. Chem. A, 2020, 8, 1378-1385.

[29] Z. Chen, W. B. Gong, Z. B. Liu, S. Cong, Z. H. Zheng, Z. Wang, W. Zhang, J. Y. Ma, H. S. Yue, G. H. Li, W. B. Lu, W. C. Ren, Z. G. Zhao, Nano Energy., 2019, 60, 394-403.

[30] J. Mahmood, F. Li, C. Kim, H. J. Choi, O. Gwon, S. M. Jung, J. M. Seo, S. J. Cho, Y. W. Ju, H. Y. Jeong, G. Kim, J. B. Baek, Nano Energy, 2018, $44,304-310$.

[31] J. Hafner, J. Comput. Chem., 2008, 29, 2044-2078.

[32] J. P. Perdew, K. Burke, M. Ernzerhof, Phys. Rev. Lett., 1996, 77, 3865-3868.

\section{Graphical Abstract}

Chin. J. Catal., 2021, 42: 1160-1167 doi: 10.1016/S1872-2067(20)63745-7

Transition-metal-atom-pairs deposited on g-CN monolayer for nitrogen reduction reaction: Density functional theory calculations

Bin Huang, Yifan Wu, Bibo Chen, Yong Qian, Naigen Zhou *, Neng Li * East China University of Technology; Wuhan University of Technology; Nanchang University;

Shenzhen Research Institute of Wuhan University of Technology;

Zhengzhou University

A series of atom pairs supported in g-CN were explored as electrocatalysts for $\mathrm{N}_{2}$ fixation based on DFT calculations. A stable $\mathrm{Co}_{2} @ \mathrm{CN}$ may be a strongly competitive material for the electroreduction of nitrogen with high selectivity and a relatively low overpotential.

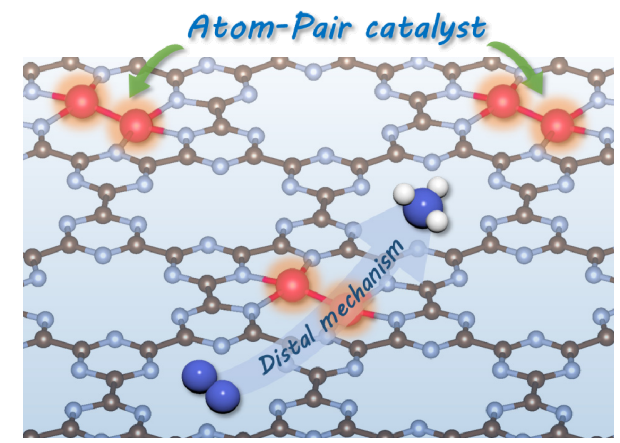


[33] P. E. Blochl, Phys. Rev. B, 1994, 50, 17953-17979.

[34] S. Grimme, J. Comput. Chem., 2006, 27, 1787-1799

[35] W. Tang, E. Sanville, G. Henkelman, J. Phys-Condens. Mat., 2009, 21, 084204.

[36] K. Momma, F. Izumi, J. Appl. Crystallogr., 2011, 44, 1272-1276.

[37] J. K. Nørskov, J. Rossmeisl, A. Logadottir, L. Lindqvist, J. R. Kitchin, T. Bligaard, H. Jonsson, J. Phys. Chem. B, 2004, 108, 17886-17892.

[38] C. Wang, C. Y. Zhu, M. Zhang, Y. Geng, Z. M. Su, Adv. Theory Simul., 2020, 3, 2000218.

[39] X. Zhang, A. Chen, Z. H. Zhang, Z. Zhou, J. Mater. Chem. A, 2018, 6, 18599-18604.
[40] C. Cheng, X. L. Zhang, Z. X. Yang, Z. Zhou, ACS Appl. Mater. Interfaces, 2018, 10, 32903-32912.

[41] C. Y. Ling, X. H. Niu, Q. Li, A. J. Du, J. L. Wang, J. Am. Chem. Soc., 2018, 140, 14161-14168.

[42] Q. Y. Cui, G. Q. Qin, W. H. Wang, G. K. Rangaswamy, A. J. Du, Q. Sun, J. Mater. Chem. A, 2019, 7, 14510-14518.

[43] J. H. Montoya, C. Tsai, A. Vojvodic, J. K. Nørskov, ChemSusChem, 2015, 8, 2180-2186.

[44] H. Xu, D. Cheng, D. Cao, X. C. Zeng, Nat. Catal., 2018, 1, 339-348.

[45] L. Zhang, S. Mallikarjun Sharada, A. R. Singh, B. A. Rohr, Y. Su, L. Qiao, J. K. Nørskov, Phys. Chem. Chem. Phys., 2018, 20, 4982-4989.

\title{
过渡金属原子对掺杂g-CN单层作为高效氮电催化剂性能
}

\author{
黄 斌 ${ }^{\mathrm{a}, \mathrm{b}}$, 吴亦凡 ${ }^{\mathrm{c}}$, 陈碧波 ${ }^{\mathrm{a}}$, 钱 勇 ${ }^{\mathrm{a}}$, 周耐根, ${ }^{\mathrm{c}, \#}$, 李 能 $\mathrm{b}, \mathrm{d}, \mathrm{e},{ }^{*}$ \\ a东华理工大学核资源与环境国家重点实验室, 江西南昌330031 \\ b武汉理工大学建筑硅酸盐材料国家重点实验室, 湖北武汉 430070 \\ c 南昌大学材料科学与工程学院, 江西南昌 330031

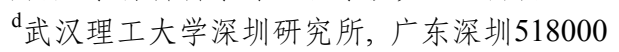 \\ e郑州大学材料科学与工程学院国家低碳与环境材料国际合作研究中心(CDLCEM), 河南郑州450001
}

\begin{abstract}
摘要: 由于氨是药物、肥料和树脂等领域的基础, 氨合成一直广受关注. 工业中主要通过Haber-Bosch反应制备氨, 反应需 要在高温高压下进行. 因此, 探索其它氨合成技术对减轻能源消耗和缓解温室效应具有重大意义. 在溶液条件下, 采用水 作为氢质子源, 电化学还原氮合成氨方法受到了极大关注. 然而, 大多数电催化剂难以活化氮气分子且电催化氮气还原过 程中存在副反应竞争, 因此, 研发高效的电催化材料仍然是一个重要研究领域. 研究人员探索了多种电催化材料, 其中, 双 原子对催化剂成为电催化领域的研究热点. 与单原子催化剂相比, 双原子对催化剂不仅具有低配位的金属原子, 而且可以 通过调节额外分散的金属原子来改善多数电催化反应性能. 作为一种新型碳氮材料, 二维 $\mathrm{g}-\mathrm{CN}$ 具有高表面积、多孔结构以 及出色的光学活性和热力学稳定性, 可以与金属原子对良好地适配, 是一种有潜力的基底材料. 然而, 目前有关金属双原 子对负载在 $\mathrm{g}-\mathrm{CN}$ 单层上作为电催化剂催化 $\mathrm{N}_{2}$ 分子还原性能尚不清楚.

本文采用密度泛函理论计算研究了 $\mathrm{N}_{2}$ 分子在过渡金属原子对 $(\mathrm{TM}=\mathrm{Sc} \sim \mathrm{Zn})$ 掺杂 $\mathrm{g}-\mathrm{CN}$ 单层上的吸附和活化, 根据吉布 斯自由能详细地研究了电催化合成氨的电化学机理. 计算发现, 在 $\mathrm{Fe}_{2} @ \mathrm{CN}$ 和 $\mathrm{Co}_{2} @ \mathrm{CN}$ 催化剂上, 其决速步骤的自由能变化 分别为 0.47 和 $0.78 \mathrm{eV}$. 对于 $\mathrm{Fe}_{2} @ \mathrm{CN}, \mathrm{N}_{2}$ 电还原反应机制遵循末端路径, 而在 $\mathrm{Co}_{2} @ \mathrm{CN}$ 上, 其还原过程为末端或混合路径. 由于 $\mathrm{Co}_{2} @ \mathrm{CN}$ 对析氢反应的抑制效果较好, 因此该电催化材料体系极具竞争力. 相比于 $\mathrm{Co}_{2} @ \mathrm{CN}, \mathrm{Fe}_{2} @ \mathrm{CN}$ 具有较好的氮气 活化性能, 但选择性较差. 另外, $\mathrm{N}_{2}$ 分子与 $\mathrm{Fe}_{2} @ \mathrm{CN}$ 和 $\mathrm{Co}_{2} @ \mathrm{CN}$ 之间存在电荷的接受-给予过程, 这在活化情性 $\mathrm{N}_{2}$ 分子中氮原 子间的三键上起到了关键作用. 第一性原理分子动力学模拟结果表明, $\mathrm{Fe}_{2} @ \mathrm{CN}$ 和 $\mathrm{Co}_{2} @ \mathrm{CN}$ 表现出较高的结构稳定性. 因 此, 本文深入探讨了过渡金属原子对掺杂 $\mathrm{g}-\mathrm{CN}$ 单层催化剂上的氮气还原效率及机制, 为合理设计该系列的高效、低成本电 催化剂提供理论依据.
\end{abstract}

关键词: 原子对催化剂; 石墨氮化碳单层; 氮还原反应; 二维材料; 密度泛函理论

收稿日期: 2020-09-01. 接受日期: 2020-11-26. 上网时间: 2021-03-05.

*通讯联系人. 电子信箱: lineng@whut.edu.cn

\#通讯联系人. 电子信箱: ngzhou@ncu.edu.cn

基金来源：高等学校学科创新引智计划(111项目, B18038); 深圳市科创委基础研究(JCYJ20190809120015163); 霍英东高等学校 青年教师教育基金(161008); 湖北省杰青项目(2020CFA087); 江西省教育厅基金(GJJ180365); 东华理工大学核资源与环境重点 实验室基金(NRE1411).

本文的电子版全文由Elsevier出版社在ScienceDirect上出版(http://www.sciencedirect.com/journal/chinese-journal-of-catalysis). 